\title{
Fatores de risco da osteoporose: prevenção e detecção através do monitoramento clínico e genético
}

Osteoporosis risk factors:

prevention and detection through clinical and genetic monitoring

\section{Nívea Dulce Tedeschi Conforti Froes ${ }^{1}$, Edgard dos Santos Pereira ${ }^{2}$ e Wilson Fábio Negrelli ${ }^{3}$}

\section{RESUMO}

A osteoporose é uma doença sistêmica caracterizada pela baixa massa óssea e deterioração da micro arquitetura do tecido ósseo. Consequentemente existe um aumento na fragilidade do osso e suscetibilidade à fratura, que é considerada o efeito clínico mais importante deste processo. Muitos estudos que se utilizam de modelos em gêmeos ou pais e seus descendentes têm confirmado o papel da herança genética no pico de massa óssea, na verdade o maior fator de risco da fratura. Neste artigo de revisão, são enfocados os prováveis genes envolvidos no processo de osteoporose, ressaltando a importância das interações entre genegene e gene-ambiente. Concernente à influência isolada do ambiente, são abordados os hábitos relacionados ao estilo de vida, à nutrição e ao tabagismo envolvidos no aparecimento dessa doença. Durante os próximos anos, o conhecimento baseado na genética molecular elucidará o processo osteoporótico. Do mesmo modo, os estudos clínicos se expandirão, visando contribuir para a detecção precoce da doença, permitindo assim a aplicação de medidas preventivas e terapêuticas adequadas.

Descritores: Osteoporose. Aspectos genéticos. Prevenção. Detecção.

\section{ARTIGO DE REVISÃO}

A osteoporose é uma doença metabólica do osso, que se caracteriza por baixa massa e deterioração do tecido ósseo, conduzindo à fragilidade do osso com conseqüente aumento do risco de fraturas. Estudos familiais sugerem a osteoporose como uma doença genética, de caráter poligênico, sendo que mais de 85\% da variação de massa óssea está sob controle genético(62).

A massa óssea resulta tanto da quantidade de osso adquirida durante o crescimento, ou seja, o pico de massa óssea, e

\section{SUMMARY}

Osteoporosis is a systemic disorder characterized by low bone mass and microarchitectural deterioration of bone tissue. Consequently, there is an increase in bone fragility and susceptibility to fracture, which is considered the most important clinical outcome of this process. Several studies using twins or parents- offspring models have confirmed the strong heritability of peak bone mass, in fact, the major risk factor of fracture. In this review article, we focused on the candidate genes involved in osteoporosis, pointing out the importance of the interaction between gene-gene and gene-environment. Concerning the environmental influence itself, we approach about life style, nutrition and smoke habit related with the disease onset. During the coming years, knowledge on the genetic molecular basis will elucidate the osteoporosis process. At the same way, clinical studies will expand in order to contribute to early detection of the disease, thus allowing application of adequate preventive and therapeutic measures.

Key words: Osteoporosis. Genetic aspects. Prevention. Detection

\section{REVIEW ARTICLE}

Osteoporosis is a metabolic disease characterized by low bone mass and deterioration of bone tissue, which leads to impaired skeletal strength and increased susceptibility to fracture. Familial studies have suggested osteoporosis as a genetic disease with involvement of different genes and the majority (85\%) of bone mass variation is under genetic contro/(62).

Bone mass means the difference between maximum mineral density content acquired during growth and the conse-
1- Mestre e Doutora em Genética pela Universidade Estadual Paulista, UNESP; Pós-Doutorado pela Universidade do Texas, Departamento de Medicina Preventiva, Galveston, EUA. 2- Professor de Ortopedia, Faculdade de Medicina da Universidade de Santo Amaro - UNISA Coordenador de Residência Médica do Hospital Geral da Vila Penteado - Sáo Paulo. 3- Ortopedista e Traumatologista. Coordenador do Grupo de Cirurgia da Coluna do Hospital Geral da Vila Penteado - São Paulo.

Endereço para correspondência: Laboratório de Epidemiologia Molecular - Universidade Estadual Paulista - UNESP, Campus de São José do Rio Preto. Rua Cristóvão Colombo, 2265 - CEP 15054-000 São José do Rio Preto, SP - E-mail: nfroes@bot.ibilce.unesp.br

Trabalho recebido em 25/07/2001. Aprovado em 27/11/2001
1- Master and PhD in Genetics by Universidade Estadual Paulista, UNESP; Post-Doc by Texas University, Preventive Medicine Department, Galveston, USA 2- Chairman, Faculdade de Medicina Unisa; Co-ordinator of Medical Residency from Hospital de Vila Penteado

3- Orthopedist and Traumatologist. Spine Surgery Group Co-ordinator from Hospital de Vila Penteado

Adress: Laboratório de Epidemiologia Molecular - Universidade Estadual Paulista - UNESP, Campus de São José do Rio Preto. Rua Cristóvão Colombo, 2265 - CEP 15054-000 São José do Rio Preto, SP E-mail: nfroes@bot.ibilce.unesp.br 
a razão de perda óssea relacionada com a idade. Essas mudanças ocorrem durante o processo de remodelação no osso, como resultado do desequilíbrio entre as células de reabsorção (osteoclastos) e as células formadoras (osteoblastos) que removem e recolocam pequenos pacotes de osso em certos pontos do esqueleto. Desse modo, percebe-se que o osso nunca está metabolicamente inativo, sua matriz e suplementos minerais estão sendo remodelados constantemente, ao longo das linhas de estresse mecânico(40).

Em conseqüência de ser uma patologia silenciosa, que pode progredir sem detecção por décadas, a osteoporose afeta miIhões de pessoas e está se tornando um dos maiores problemas de saúde. Assim, a osteoporose atinge tanto homens como muIheres e tem um impacto comparável, se não maior, aos mais importantes problemas de saúde, como as doenças cardiovasculares e o câncer.

Atualmente, os custos relacionados à osteoporose estão sendo considerados como o maior encargo para as autoridades de saúde dos países desenvolvidos. Somente nos Estados Unidos, o dispêndio do tratamento supera a cifra de 10 bilhões de dólares anuais, havendo mais de vinte e cinco milhões de indivíduos afetados, sendo $12 \%$ de homens e $40 \%$ de mulheres ${ }^{(13)}$. Estima-se que a ocorrência de perda óssea atinja cerca de um quarto da população em todo o mundo, o que pode ser estimado em até 220 milhões de pessoas ${ }^{(49)}$.

A fratura é o efeito clínico mais importante da osteoporose. Dada à mortalidade associada com fraturas osteoporóticas, a significância dessa doença não pode ser ignorada. O reparo de fraturas envolve passos fisiológicos complexos, com a participação coordenada de muitos tipos celulares ${ }^{(18)}$. Durante os últimos anos, a genética molecular tem se tornado de extrema significância para a pesquisa médica ${ }^{(44)}$, fornecendo metodologias capazes de identificar mecanismos importantes nos processos fisiológicos e patofisiológicos, incluindo aqueles envolvidos na consolidação de fraturas, que ocorre ao nível molecular ${ }^{(26)}$.

A partir do conhecimento acerca dos fatores genéticos envolvidos e sua potencial interação com o ambiente será possível à escolha do melhor caminho para a prevenção, detecção e tratamento da osteoporose e as conseqüências dela advindas. Considera-se a interferência genética na osteoporose como um processo claro, envolvendo parâmetros como modulação da densidade, tamanho e forma do osso ${ }^{(15)}$.

A fragilidade esquelética é amplamente determinada pela massa e a micro- estrutura do osso. O pico de massa óssea é o maior fator na quantificação de risco à fratura ${ }^{(51)}$ e variações alélicas no gene receptor da vitamina D (VDR) têm sido relatadas como responsáveis pela alteração da homeostase de cálcio, com efeitos subsequentes sobre o tamanho e a densidade óssea ${ }^{(12,20,48,55,62)}$. Indivíduos portadores de genótipos desfavoráveis, ou seja, com a presença de mutações em sítios específicos para o gene VDR, apresentam maior prevalência e incidência de fraturas e perda de massa óssea ${ }^{(5,23,24)}$. No entanto, não há concordância completa entre os dados de literatu$\mathrm{ra}^{(63)}$. Uma explicação plausível para isso seja a necessidade de se considerar as interações entre gene e idade ${ }^{(21)}$, gene e ambiente ${ }^{(20)}$ e principalmente, a interação entre diferentes genes na densidade mineral óssea ${ }^{(19)}$. quent loss verified during senility period. Those changes occur during bone remodeling process as a result of re-absorption cells (osteoclasts) and forming cells (osteoblasts) disequilibrium that remove and replace bone packages in discrete points of the skeletal. According of this, it can be noticed that the bone is an alive tissue, its matrix and mineral supplements are remodeling constantly along the mechanical stress lines ${ }^{(40)}$.

Osteoporosis is a silent disease that progresses without any outward sign, sometimes for decades. It affects thousands of people and for this reason it has been considered a world health problem that hampers the quality of life, mainly in elderly people.

Nowadays, the costs related to osteoporosis have been considered as the major concern for the authorities in developed countries. In the United States, the treatment cost is beyond $U \$ 10$ billion annually. There are more than 25 million affected people, $12 \%$ males and $40 \%$ females $^{(13)}$. It has been estimated that bone loss reaches more than 220 million people, which represent $1 / 4$ world population ${ }^{(49)}$.

Fracture is considered the most important clinical feature in osteoporosis. Its repair involves complex physiological steps with the coordinated participation of different cells ${ }^{(18)}$. Lately, the molecular genetics became a powerful tool for medical research ${ }^{(44)}$, enabling to identify important mechanis$m s$ involved in fracture healing that occurs at molecular level, through new methodologies ${ }^{(26)}$.

The genetic role in osteoporosis has been considered as a clear process involving density modulation and shape and size of the bone ${ }^{(15)}$. The skeletal fragility is determined by bone micro-structure and mass. The bone mass pick is the main issue for quantification of risk fracture ${ }^{(51)}$ and allelic variations in the vitamin $D$ receptor gene (VDR) has been related as responsible for calcium metabolism with subsequent effects on bone density and size ${ }^{(12,20,48,55,62)}$. Individuals bearing unfavorable genotypes with the presence of mutation at specific sites of VDR gene, present higher fractures incidence and prevalence, besides bone mass loss ${ }^{(5,23,24)}$. Nevertheless, contradictory data have been presented ${ }^{(63)}$ that did not find association between VDR mutation and osteoporosis risk in Afro- American women. According of this, the theory that it has to be considered the ethnic differences is reinforced, once the genetic inheritance is preponderant regarding the development of the disease. Furthermore, it has also to be considered the gene-age ${ }^{(21)}$, gene-gene ${ }^{(20)}$ and gene-environmental interactions ${ }^{(19)}$.

Recently, it was emphasized the interaction between the VDR and estrogen receptor gene (ER) in bone density ${ }^{(12)}$ which corroborates with the hypothesis that the better is the understanding of the disease, the better is the treatment focusing bone mass preservation. The estrogen influences on bone metabolism and developing and this effect depends on nuclear receptor ${ }^{(47)}$. Caucasian American women that are ER mutant present significant low mineral density compared to those who have normal genotypes ${ }^{(63)}$. Moreover, the genetic variation at the locus, singly and in relation to the Vitamin $D$ receptor gene, influences attainment and maintenance of 
Concernente a esse último aspecto, a existência de uma possível interação entre os genes VDR e o receptor de estrógeno (ER) associado diretamente com a densidade óssea foi relatada recentemente ${ }^{(12)}$, corroborando, portanto, com a hipótese de que o melhor esclarecimento dessa interação pode auxiliar no tratamento de preservação da massa óssea. O estrógeno influencia o metabolismo e crescimento ósseo e esse efeito é dependente de receptores nucleares ${ }^{(47)}$. Mulheres caucasianas americanas, mutantes recessivas para o gene, apresentam densidade óssea significativamente mais baixa, em comparação às mulheres portadoras de genótipos normais ${ }^{(63)}$. Além disso, a variação genética no loco ER, como evento único ou combinado com o gene VDR influenciaa obtenção e manutenção do pico de massa óssea em mulheres jovens, o que pode em troca, conferir indivíduos mais suscetíveis à osteoporose, em comparação a outros ${ }^{(4)}$. É importante salientar que existe uma potencial ligação fisiológica entre o gene ER e a vitamina $D$, pois essa regula a P450 aromatase, enzima que modula, por sua vez, a disponibilidade do estrógeno ao seu receptor, expresso nos osteoblastos.

A calcitonina é um hormônio polipeptídico secretado pelas células parafoliculares da glândula tiróide, capaz de inibir a reabsorção osteoclástica do osso e estimular a excreção urinária do cálcio. Em um estudo visando determinar o papel do gene que codifica para o receptor da calcitonina (CTR) na densidade mineral óssea ${ }^{(41)}$, o genótipo heterozigoto $(\mathrm{Tt})$ foi o mais representado nas mulheres normais, como as portadoras de osteoporose. Entretanto, as mulheres com genótipo recessivo (tt) mostraram menor densidade mineral óssea na região lombar, em comparação ao genótipo heterozigoto.

Em contraposição, não foram observadas variações significativas na densidade mineral óssea do colo do fêmur. Essas observações estão de acordo com a teoria de que há forte influência genética na constituição da massa óssea em sítios com maior proporção de osso trabecular e igualmente com a especificidade genética para sítios anatômicos. As formas polimórficas para CTR podem realçar diferenças genéticas na suscetibilidade à perda de massa óssea, bem como na resposta aos tratamentos.

De acordo com esses resultados, o gene CTR se torna um novo candidato no cenário de genes que influenciam a determinação da densidade mineral óssea.

O colágeno tipo I é a proteína extracelular mais abundante da matriz óssea e é essencial para a força esquelética. Cada molécula de colágeno tipo I é composta de duas cadeias alfa 1 e uma cadeia alfa 2 entrelaçadas entre si, formando uma hélice tríplice. O gene do colágeno tipo I alfa 1 (COLIA1) está associado com a massa óssea e propensão à fraturas e se caracteriza por conter um sítio polimórfico, conhecido como Sp1. Resultados publicados ${ }^{(37)}$ demonstraram que tanto homens como mulheres, portadores do genótipo recessivo são propensos à fratura. Isso sugere que o loco polimórfico Sp1 do COLIA1 pode estar relacionado com a qualidade do colágeno no esqueleto. Do mesmo modo, o gene COLIA1 pode estar implicado na determinação da força e massa óssea.

Similarmente, diferenças significativas na distribuição genotípica foram encontradas nos pacientes com osteoporose, quando comparados aos controles saudáveis. Tais achados reforçam que o estudo desse polimorfismo pode ser de extremo valor clínico na identificação de indivíduos, tanto do sexo masculino como feminino, que apresentam risco para fraturas. peak bone mass in younger women, which in turn may render some individuals more susceptible to osteoporosis than others ${ }^{(4)}$. There is a potential physiologic link between the ER and vitamin $D$. The vitamin $D$ is among the hormones that regulate $P 450$ aromatase and this enzyme, which modulates availability of estrogen to its receptor, is expressed in osteoblasts.

One of the hormones involved in bone metabolism is calcitonin, a polypeptide hormone secreted by parafollicular cells of the thyroid gland, able to inhibit osteoclastic bone resorption and to stimulate urinary calcium excretion. The role of the gene encoding for a peptide hormone receptor (CTR) was evaluated(41) in BMD determination in a population of Italian postmenopausal women. They found that genotype Tt was the most frequently represented in both osteoporotic and normal women. Women with tt genotype showed a lower spinal BMD in comparison with those the Tt genotype. Otherwise, no significant variations of BMD among the genotypes were observed in the femoral neck BMD. This observation is in agreement with a stronger genetic influence on bone mass at sites with higher proportions of trabecular bone and with a genetic specificity for anatomical sites. Polymorphic forms of CTR may underlie individual differences in susceptibility to bone mass loss and to responsiveness to treatment regimens.

According to this, the CTR gene becomes a new candidate in the scenario of genes influencing BMD determinations.

The collagen type 1 is the most abundant bone extracellular protein, moreover is essential for skeletal strength and also associated with bone mass and fracture predisposition. It contains a polymorphic site named Sp1, recessive mutations are related with fracture prone ${ }^{(37)}$. This suggests that COL1A1-Sp1 polymorphic locus could be related to the quality of collagen in the skeleton. Altogether, these results suggest that COL1A1 gene may be implicated in the determination of bone mass or strength. Significant differences on genotypic distribution were encountered in osteoporotic patients when compared with control people, therefore the study of this polymorphism can contribute for clinical identification of at risk individuals, both males and females.

Another candidate gene is the apolipoprotein E (APOE) that acts as a ligand for low density lipoprotein receptors and facilitates intro-vascular transport of lipids and vitamin $K$, a co-factor for the $g$ - carboxiglutamin formation of many bone matrix proteins ${ }^{(7)}$. One possible explanation for the APOE gene and fracture occurrence is that it can interfere in vitamin Kabsorption ${ }^{(30,31)}$. As already known, vitamin K modulates the gama-carboxilation of glutamine residues in most bone proteins, mainly osteocalcin, therefore, high decarboxilated osteocalcin and low concentrations of vitamin $K$ are associated to low mineral density and consequently to a higher fracture risks. Recently(7), it was reported that women bearing at least a mutant allele of APOE gene are under a elevated risk of hip and wrist fractures, data confirmed by others.

There is no doubt about genetic involvement on bone modulation, shape and size. No matter the age or life period, 
Um outro gene que figura como candidato no processo da osteoporose é o do apolipoproteína E (APOE), que atua como ligante para os receptores de lipoproteínas de baixa densidade e facilita o transporte intravascular de lipídeos e vitamina K, um cofator para a formação de resíduos de $\gamma$-carboxiglutamato de muitas proteínas da matriz óssea ${ }^{(7)}$. Uma possível explicação para a participação do gene APOE no aparecimento de fraturas parece residir no fato de que ele pode alterar a absorção de vitamina $K^{(30,31)}$. A vitamina $K$, como se sabe, media a gama carboxilação dos resíduos de glutamil em muitas proteínas ósseas, principalmente a osteocalcina. Assim sendo, altas concentrações de osteocalcina descarboxilada e baixas concentrações de vitamina $\mathrm{K}$ estão associadas à menor densidade mineral óssea e conseqüente aumento do risco de fraturas. Relatos recentes ${ }^{(7)}$ indicam que mulheres portadoras de, pelo menos, um alelo mutado do gene possuem risco aumentado de fraturas nos quadris e pulso, resultados esses confirmados por outros autores.

Pelo exposto, não há dúvida sobre a evidente participação genética na densidade, forma, tamanho e modificação óssea. Em qualquer idade ou fase da vida, a herança genética contribui de modo significativo nesses processos, embora haja a interação do genótipo com fatores do ambiente, tais como a dieta e o estilo de vida durante o tempo todo ${ }^{(15)}$, podendo essa interação interferir na penetrância do gene ${ }^{(54)}$. Em conseqüência disso, tem sido crescente o interesse, além dos estudos descritivos populacionais na espécie humana, de estudos que decifrem a variabilidade individual ou populacional na suscetibilidade às doenças ${ }^{(1)}$. Portanto, decifrar a base genética da variação na resposta a agentes ambientais pode responder questões sobre porquê certos grupos de indivíduos apresentam maior incidência de uma doença específica, da mesma forma que se constituiria em um forte instrumento de prevenção à essas doenças.

Dentre os marcadores disponíveis para os estudos em sistemas biológicos, os marcadores de efeito indicam a presença de doenças ou precursores de doenças e os marcadores de suscetibilidade indicam indivíduos ou populações com diferenças biológicas capazes de afetar a resposta do organismo àagentes ambientais ${ }^{(9)}$. Esses marcadores constituem, portanto, ferramentas indispensáveis que podem ser adotadas como estratégias de prevenção ${ }^{(35,60)}$. Além disso, os marcadores genéticos poderão em futuro próximo, ser utilizados não apenas em estudos epidemiológicos, como também na prática clínica.

Dentre os fatores ambientais envolvidos no processo osteoporótico, a nutrição, particularmente com relação ao consumo de proteínas, produtos lácteos everduras, tem sido referida como contribuidora da formação da massa óssea ${ }^{(3,50,52)}$. A suplementação de cálcio e vitamina $D$ na infância parece também desempenhar papel importante na saúde dos ossos $^{(61)}$. Estudos retrospectivos em adultos sugerem que o consumo de cálcio na primeira fase do desenvolvimento está associado com o risco de ocorrência de fraturas e o desenvolvimento de osteoporose na fase adulta ${ }^{(56,59)}$. Entretanto, há que se considerar que a sensibilidade de absorção desse nutriente varia dependendo da constituição genética do indivíduo ${ }^{(42)}$.

O uso de cafeína, o consumo de álcool e o hábito tabagista parecem influir na diminuição da densidade óssea ${ }^{(33,58)}$. Com relação à cafeína, seu efeito provavelmente está associado com o aumento na excreção de cálcio.De um modo geral, o consumo diário de mais de duas xícaras está moderadamente associado com o aumento de fraturas ${ }^{(34)}$. Contudo, outros autores discor- the genetic inheritance plays a important role in those processes although there is an interaction between genes and environmental factors, such as diet and life style ${ }^{(15)}$ which interfere in the penetrance of the gene ${ }^{(54)}$. According to that, beyond descriptive population studies, there is an increased interest concerning the role of individual or population variability in the disease susceptibility ${ }^{(1)}$. Thereby, to decode the genetic basis of response variability to environmental xenobiotic can answer questions such as why certain groups present higher incidence of an specific disease. In the same manner, it would constitute a strong tool focusing on prevention of a ill condition.

Among the available biomarkers for biological system researches, the effect markers indicate the presence of diseases or its precursors and susceptibility markers indicate biological individual differences capable to affect the response of an organism to environment agents ${ }^{(9)}$. Those markers constitute unique tolls to be adopted as prevention strategies ${ }^{(35,60)}$. Besides, the genetic markers will be utilized in a close future not only in epidemiologic studies and in clinical practices, as well.

Among the environmental factors involved in osteoporotic process, the nutrition, mainly related with protein intake, dairy products and vegetables are referred to enhance bone mass formation ${ }^{(3,50,52)}$. The calcium and vitamin $\mathrm{K}$ supplements during childhood seem to contribute with bone health(61). Retrospective studies in adults suggest that the calcium intake during the first phase of development are associated with the occurrence of risk fracture and osteoporosis onset in elderly phase ${ }^{(56,59)}$. However, it is important to consider that the absorption capacity varies depending on genetic individual constitution ${ }^{(42)}$.

The caffeine and alcohol intake along with the smoke habit seem to decrease bone density ${ }^{(33,58)}$. Most likely, caffeine effect is associated with the increase of calcium excretion. Overall, daily intake of more than two cups is moderately associated with the increase of fracture risk ${ }^{(34)}$. These data are not corroborated by other authors that affirm there is no consistence between caffeine intake, risk fracture and osteoporosis development ${ }^{(10,39)}$.

Concerning smoke habit and alcohol intake there is less inconsistency, once cigarette smoke is considered as a moderate risk factor for osteoporosis ${ }^{(57)}$. The chemical cigarette components, including nicotine, acting as a depressor of osteoblast cell activity, both directly or by hormonal pathway ${ }^{(29,36)}$. An average bone mineral density of 5 to $10 \%$ deficit and a detrimental effect as well are reported in smoke people ${ }^{(38)}$, reason why the cigarette is related with an increase risk of fractures ${ }^{(28)}$ and as a bone loss inducer, both in males and females. These consequences are probably due to the cigarette anti-estrogenic effect which reduces estradiol level and the increase of sexual hormone globulin ligand ${ }^{(11,14,27)}$. It has to be point out that the deleterious cigarette effects are not restricted to elderly people, once there ${ }^{(46)}$ is data reporting bone mass loss in young and health men, considered heavy smokers (more than 21 cigarettes/day). 
dam desses resultados, afirmando ser inconsistente a associação da cafeína com o aumento do risco de fratura e o desenvolvimento da osteoporose ${ }^{(10,39)}$.

Uma menor inconsistência de resultados ocorre, todavia concernente à relação entre o hábito tabagista e o consumo de álcool com o risco de fraturas ${ }^{(57)}$. O cigarro é considerado fator de risco moderado para a osteoporose ${ }^{(29,36)}$, uma vez que os componentes químicos do cigarro, entre eles a nicotina, atuam deprimindo a atividade do osteoblasto, tanto diretamente como por via hormonal ${ }^{(38)}$. Déficit médio de 5 a 10\% na densidade óssea de indivíduos fumantes também são relatados ${ }^{(28)}$. Por seu efeito prejudicial na densidade mineral óssea, o cigarro tem sido também apontado como capaz de aumentar o risco à fraturas ${ }^{(42)}$, bem como induzir a perda de massa óssea em homens e mulheres, provavelmente pelo seu efeito antiestrogênico, que reduz o nível de estradiol e o aumento de globulinas ligantes de hormônios sexuais ${ }^{(11,14,27)}$. É pertinente ressaltar que os efeitos deletérios do cigarro não ficam restritos apenas a indivíduos idosos. Há relatos ${ }^{(46)}$ de perda de massa óssea em homens jovens e saudáveis, considerados fumantes pesados (mais de 21 cigarros/dia).

Relativo ao consumo de álcool, parece haver um efeito direto sobre os osteoblastos, determinando diminuição nos níveis de osteocalcina nos estágios iniciais, além de mudanças histomorfométricas em etapas posteriores. Há também relatos não somente da diminuição da formação óssea, bem como aumento de reabsorção(17,32). Em alcoólatras crônicos, os níveis séricos de vitamina D e seus metabólitos diminuem, independentemente da presença de qualquer hepatopatia. O consumo de bebidas alcoólicas que excede a $200 \mathrm{ml}$ por semana pode interferir nos níveis estrogênicos e isso estaria associado com o aparecimento da osteoporose ${ }^{(22)}$.

A atividade física tem sido apontada como fator que contribui para o aumento da massa óssea, reduzindo consequentemente o risco de fraturas ${ }^{(25)}$. Os benefícios específicos de um programa regular de exercícios incluem o controle da obesidade, o aumento do perfil lipídico no sangue e a otimização da ingestão de micronutrientes ${ }^{(45,53)}$. Aconselha-se o exercício físico desde a infância, por ser esse o período de formação da massa óssea ${ }^{(6)}$. Ao mesmo tempo, a atividade física exagerada durante a puberdade deve ser evitada, uma vez que numerosos estudos demonstram distúrbios hormonais ao nível do eixo pituitário do hipotálamo em atletas jovens ${ }^{(2)}$.

Diante das informações apresentadas parece evidente que conhecer a fisiologia molecular dos genes e a interação entre eles no processo da osteoporose conduzirá certamente ao melhor entendimento dessa patologia, facilitando o diagnóstico e tratamento. Ao mesmo tempo, esse conhecimento auxiliará sobremaneira na identificação e detecção de grupos de risco, bem como propiciará a condução de tratamentos individualizados específicos, por permitir a seleção de opções terapêuticas mais apropriadas ${ }^{(16)}$.

O uso de marcadores moleculares aliado ao acompanhamento clínico especializado é a ferramenta precisa no entendimento da etiologia da doença, bem como na detecção dos fatores de risco. Esse tipo de monitoramento abrange o valor preventivo, que em futuro breve será requerido em larga escala, proporcionando a melhora na qualidade de vida de um modo geral.

Seu emprego, contribuirá de forma singular para diminuir a incidência dessa patologia, considerada problema de saúde mundial.
Concerning alcohol intake it seems to have a direct effect on osteoblast cells which determines a decrease in osteocalcin levels during the early stages and hystomorphometric changes in further stages. Besides the decreasing effect in bone formation, it is also reported an re-absorption increase ${ }^{17,32)}$. In chronic alcoholic people, the seric levels of vitamin $D$ and its metabolites diminish, independently of any hepatic anomaly. The alcoholic consuming that exceeds $200 \mathrm{ml}$ weekly may interfere in estrogenic levels which can be associated with osteoporosis onset ${ }^{(22)}$.

The physical activity has been pointed as a contributor factor that promotes bone mass increase, consequently reducing the fracture risk ${ }^{(25)}$. The specific benefits of a regular exercise program include the weight control, the increase of lipid blood profile and micro-nutrients ingestion ${ }^{(45,53)}$. The physical activity is counseled since childhood, because this is the period when the bone mass is formed(6). At the same time, physical over-activity during youth has to be avoided due to hormonal imbalance verified in young athletes ${ }^{(2)}$.

According to the present information it seems evident that knowing the molecular physiologic effect of the involved genes in osteoporosis will certainly lead to better understanding of the disease, making the diagnosis easier and mainly helping in the identification and detection of at risk groups, propitiating a specific management of individual treatment as well, by enabling the selection of therapeutic more appropriated options ${ }^{(16)}$.

The use of molecular markers allied to clinical follow up are the precise tool in the ethiology understanding and the risk factors detection as well. This kind of monitoring perfor$m s$ a preventive approach which in a close future will be required in large scale to proportionate a better quality of life. It will contribute in a unique way to diminish the osteoporosis incidence, considered a global health problem. 


\section{REFERÊNCIAS}

1. Abdel-Rahman, S, El-Zein, R, Anwar, W, Au, W. A multiplex PCR procedure for polymorphic analysis of GSTM1 and GSTT1 genes in population studies. Cancer Letters, v.107, p.229-233, 1996.

2. Aebersold- Schutz, G. Do endurance sports lead to osteoporosis in women? Orthopade, v.26, p.955-960, 1997.

3. Anderson, $\mathrm{J} J$. Plant- based diets and bone health: nutritional implications. Am J Clin Nutr, v. 70, p.539-542, 1999.

4. Audi, L, Garcia-Ramirez, M \& Carrascosa, A. Genetic determinants of bone mass. Hormone Research 51, p. 105-123, 1999

5. Baltzer, A W, Reinecke, J, Wehling, P, Granrath, M, Schulit, K P. Bone density and bone metabolism regulated by vitamin $D$ receptor allele polymorphism in a German study sample. Orthop Ihre Grenzgeb, v. 137, p. 273-279, 1999.

6. Bass, S, Pearce, G, Bradney, M, Hendrich, E, Delmas, PD, Harding, A, Seeman, E. Exercise before puberty may confer residual benefits in bone density in adulthood: studies in active prepubertal and retired female gymnasts. J Bone MinerRes, v.13, p.500-507, 1998.

7. Beavan, SR, Prentice, A, Stirling, D M. Apolipoprotein E (APOE) genotype and osteocalcin carboxylation postmenopause. J. Bone Miner Res, v.13, p.523, 1998.

8. Cauley, LA, Zmuda, J M, Yaffe, K, Kuller, LH, Ferrel, RE, Wisniewski, SR, Cummings, S R. Apolipoprotein E polymorphism: a new genetic marker of hip fracture risk- The study of osteoporotic fractures. J Bone Miner Res, v.14, p. 1175-1181, 1999.

9. Conforti- Froes, N, El-Zein, R, Abdel- Rahman, S, Au, W. Predisposing genes and increased chromosome aberrations in lung cancer cigarette smokers. Mutation Research, v. 379, p.53-59, 1997.

10.Cooper, C, Atkinson, E J, Wahner, H W, O'Fallon, W M, Riggs, B L, Judd, H $L$, Melton, $L \mathrm{~J}$. Is caffeine consumption a risk actor for osteoporosis? J Bone Miner Res, v. 7, p. 465-471, 1992.

11.Daniel, M, Martin, A D, Drinkwater, D T. Cigarette smoking, steroid hormones, and bone mineral density in young women. Calcif Tissue Int., v.50, p.300 305, 1992.

12.Deng, H W, Li, J, Li, J L, Johnson, M, Gong, G, Davis, K M, Recker, R R. Change of bone mass in postmenopausal Caucasian women with and without hormone replacement therapy is associated with vitamin D receptor and estrogen receptor genotypes. Hum Genet, v. 103, p.576-585, 1998.

13.Ebeling, P R. Osteoporosis in men. New insights into aetiology, pathogenesis, prevention and management. Drugs Aging, v.13, p.421-434, 1998.

14.Egger, P, Duggleby, S, Hobbs, R, Fall, C, Cooper, C. Cigarette smoking and bone mineral density in the elderly. J Epidemiol Community Health, v. 50, p.47-50,1996.

15.Eisman, J A. Genetics of osteoporosis. Endocr Ver, v.20, p.788-804, 1999

16. Epstein, S, Goodman, G R. Improved strategies for diagnosis and treatment of osteoporosis. Menopause, v.6, p.242-250, 1999.

17.Felson, D T, Zhang, Y, Hannan, M T, Kannel, W B, Kiel, D P. Alcohol intake and bone mineral density in elderly men and women. The Framingham Study. Am J Epidemiol, v. 142, p. 485-492, 1995.

18.Ferguson, C, Alpern, E, Miclau, T, Helms, J A. Does adult fracture repair recapitulate embryonic skeletal formation? Mech Dev, v.87, p.57-66, 1999.

19.Ferrari, S, Rizzoli, R, Bonjour, J P. Genetic aspects of osteoporosis. Curr Opin Rheumatol, v.11, p.294-300, 1999.

20.Ferrari, S, Rizzoli, R, Manen, D, Slosman, D, Bonjour, J P. Vitamin D receptor gene start codon polymorphisms ( Fok I) and bone mineral density : interaction with age, dietary calcium, and 3 '-end region polymorphisms. J Bone Miner Res, v. 13, p.925-930, 1998.

21.Feskanich, D, Hunter, D J, Willett, W C, Hankinson, S E. Hollis, B W, Hough, H L, Kelsey, KT \& Colditz, G A. Vitamin D receptor genotype and the risk of bone fractures in women. Epidemiology 9 535-539, 1998.

22.Ganry, O, Dubreuil, A. The potential effects of alcohol on bone mass in menopausal women: review o the literature. Sante Publique, v.11, p.7-16, 1999.

23.Gennari, L., Becherini, L., Mansani, R, Brandi, M L. Fok I polymorphism at translation initiation site of the vitamin $D$ receptor gene predicts bone mineral density and vertebral fractures in postmenopausal Italian women. J Bone Miner Res, v.14, p.1379-1386, 1999.

24. Gomez, C, Naves, M L, Barrios, Y, Diaz, J B, Fernandez, J L, Salido, E, Torres, A, Cannata, J B. Vitamin D receptor gene polymorphisms, bone mass, bone loss and
prevalence of vertebral fracture: differences in postmenopausal women and men. Osteoporos Int, v.10, p.175-182, 1999.

25.Gregg, E W, Cauley, J A, Seeley, D G, Ensrud, KE, Bauer, D C. Study of osteoporotic fractures research group. Ann Intern Med, v. 129, p.133-134, 1998.

26. Hanselmann, R G, Mutschler, W E. Significance of molecular biology research for trauma surgery exemplified by wound and bone healing. Langenbecks Arch Chir Suppl Kongressbd, v.115, p.86-89, 1998.

27. Hollenbach, KA, Barret- Connor, E, Edeltein, SL, Hollbrook, T. Cigarette smoking and bone mineral density in older men and women. Am J Public Health, v.83, p.1265-1270, 1993.

28. Hooper, J L, Seeman, E. The bone density of female twins discordant for tobacco use. N Engl J Med, v.330, p.387-392, 1994.

29.III, P O, Alexandre, C. Tobacco as risk factor of osteoporosis, myth or reality? Rev Rhum Ed Fr, v. 60, p.280-286, 1993.

30.Johnston, C C Jr, Slemenda, C W. Pathogenesis of osteoporosis. Bone, V.17, p.19-22, 1995.
31. Johnston, J M, Cauley, J A, Ganguli, M. APOE4 and hip fracture risk in a communitybased study of older adults. J Am Geriatr Soc, v. 47, p. 1342 1345, 1999.

32.Keck, E. Alcohol-induced osteopenia. Radiologe, v.26, p. 587-591, 1986.

33. Keiver, K, Ellis, L, Anzarut, A, Weinberg, J. Effect of prenatal ethanol exposure on fetal calcium metabolism. Alcohol Clin Exp Res, v.21, p.1612 1618, 1997.

34.Kiel, D P, Felson, D T, Hannan, M T, Anderson, J J, Wilson, P W. Caffeine and the risk o hip fracture: the Framingham Study. Am J Epidemiol, v.132, p. 675 684, 1990.

35. Kulak, C A, Bilezikian, J P. Osteoporosis: preventive strategies. Int J Fertl Women Med, v. 43, p. 56-64, 1998.

36.Kyro, A., Usenius, J P, Aarnio, M, Kunnamo, I, Avikainen, V. Are smokers a risk group for delayed healing of tibial shaft fractures? Ann Chir Gynaecol, v 82, p.254-262, 1993.

37.Langdahl, B L, Ralston, S H, Grant, S F, Eriksen, E F. Na Sp1 binding site polymorphism in the COLIA1 gene predicts osteoporotic fractures in both men and women. J Bone Miner res, v. 13, p. 1384-1389, 1998

38.Laroche, M, Lasne, Y, Felez, A, Moulinier, L, Bon, E, Cantagrel, A, Leophonte P, Mazieres, B. Osteocalcin and smoking. Rev Rhum Ed Fr, v. 61, p. 433-436, 1994.

39.Lloyd, T, Rollings, N, Eggli, D F, Kieselhorst, K, Chinchilli, V M. Dietary caffeine intake and bone status of postmenopausal women. Am J Clin Nutr, v.65, p.1826-1830, 1997.

40.Marchigiano, G. Osteoporosis: primary prevention and intervention strategies for women at risk. Home Care Provid., v.2, p.76-81, 1997.

41. Masi, L, Becherini, L, Colli, E, Gennari, L, Mansani, R, Falchetti, A, Becorpi, A M, Cepollaro, C, Gonelli, S, Tanini, A, Brandi, M L. Polymorphisms of the calcitonin receptor gene are associated with bone mineral density in postmenopausal Italian women. Biochem Biophys Res Commun, v.248, p.190-195, 1998.

42. May, H, Murphy, S, Khaw, K T. Cigarette smoking and bone mineral density in older men. Q J M, v.87, p.625-630, 1994

43.Nakamura, T. The importance of genetic and nutritional factors in response to vitamin $\mathrm{D}$ and its analogs in osteoporotic patients. Calcif Tissue Int, v. 60, p. 119-123, 1997.

44.Niu, T, Chen, C, Cordell, H, Yang, J, Wang, B, Wang, Z, Fang, Z, Schork, N $\mathrm{J}$, Rosen, C J, Xu, X. A genomewide scan for loci linked to forearm bone mineral density. Hum Genet, v. 104, p. 226-233, 1999.

45.Nguyen, T V, Sambrook, P N, Eisman, J A. Bone loss, physical activity, and weight change in elderly women: the Dubbo Osteoporosis Epidemiology Study. J Bone Miner Res, v.13, p.1458 1467, 1998.

46. Ortego-Centeno, N, Munoz- Torres, M, Jodar, E, Hernandez-Quero, J, Jurado-Duce, $A$, de la HigueraTorres- $\mathrm{P} /$ uchol, J. Effect of tobacco consumption on bone minera density in healthy young males. Calcif Tissue Int, v.60, p.496-500, 1997.

47.Prakasam, G, Yeh, J K, Chen, M M, Castro-Magana, M, Liang, C T, Aloia, J F. Effects of growth hormone and testosterone on cortical bone formation and bone density in aged orchiectomized rats. Bone, v.24, p.491-497, 1999.

48. Ralston, S H. What determines peak bone mass and bone loss? Baillieres Clin Rheumatol, v.11, p.470-494, 1997.

49. Reginster, J Y, Gillet, P, Bem Sedrine, W, Brands, G, Ethgen, O, de Froidmont, $C$, Gosset, C. Direct costs of hip fractures in patients over 60 years of age in Belgium. Pharmacoeconomics, v.15,p.507-514, 1999

50.Rizzoli, R, Bonjour, J P. Malnutrition and osteoporosis. Z. Geronto/ Geriatr, v.32, p.31-37, 1999.

51.Rosen, C J, Donahue, L R. Insulin-like growth factors and bone: the osteoporosis connection revisited. Proc. Soc Exp Biol Med, v.2, p.1-17, 1998.

52.Rousseau, M E. Dietary prevention of osteoporosis. Lippincotts Prim Care Pract, v.1, p.307-319, 1997.

53.Shephard, RJ. Nutritional benefits of exercise. J Sports Med Phys Fitness, v.29, p.83-90, 1989. 54.Shiraki, M. Genetic studies in osteoporosis. Nippon Rinsho, v.56, p.1374-1381, 1998.

55.Sosa Henriquez, M., Torres Ramires, A, Dominguez, C, Salido, E, Saavedra, P, Betancor, L. Genetic polymorphism of vitamin D receptor gene and osteoporosis. Med Clin (Barc), v.110, p.636-650, 1998.

56.Stallings, VA. Calcium and bone health in children: a review. Am J Ther, v.4, p.259-273, 1997

57.Ueng, S W, Lin, S D, Wang, C R, Liu, S J, Tai, C L, Shih, C H. Bone healing of tibial lenghthening is delayed by cigarette smoking: study of bone mineral density and torsional strengh on rabbits. J Trauma, v.46, p.110-115, 1999

58.Ullom- Minnich, P. Prevention of osteoporosis and fractures. Am Fann Physician, v.60, p. 194202,1999

59.Von Muhlen, D, Visby, L, Barret-Connor, E, Bettencourt, R. Evaluation of the simple calculated osteoporosis risk estimation (SCORE) in older caucasian women: the Rancho Bernardo Study. Osteoporos Int, v.10, p.79-84, 1999.

60.Walker-Bone, K, Reid, D M, Cooper, C. Is screening for osteoporosis worthwile? Brit Med Bull, v.54, p. 915-927, 1998.

61.Wardlaw, GM. Putting osteoporosis in perspective. J Am DietAssoc, v.93, p.1000-1006, 1993.

62.Wood, R J, Fleet, J C. The genetics of osteoporosis: vitamin D receptor polymorphisms. Ver Nutr, v.18, p.233-258, 1998

63.Zmuda, J M, Cauley, J A, Ferrel, RE. Recent progress in understanding the genetic susceptibility to osteoporosis. Genet Epidemiol, v. 16, p.356-367, 1999. 